\title{
Varicella zoster virus immediate early protein 61 blocks the IFN- $\beta$ pathway by degradation the activited IRF3
}

\author{
Zhu Huifang ${ }^{*}$, Chunfu Zheng \\ From Institut Pasteur International Network Annual Scientific Meeting \\ Hong Kong. 22-23 November 2010
}

Varicella zoster virus (VZV) open reading frame 61 (ORF61) is one of the four transcription regulated proteins, which is homologous to herpes simplex virus 1 (HSV-1) ICP0 and can partially complement the function of ICP0 in ICP0 deletion mutant HSV-1. Since ICP0 can inhibit the innate immunity in many levels such as IRF3 and PML, here we investigate the role of ORF61 in helping VZV evading IFN- $\beta$ signal pathway. As the role of IFN $-\beta$ in VZV infection has little been reported previously, our results demonstrated that IFN- $\beta$ can limit VZV replication in Mewo cells and VZV infection can suppress the secretion of IFN- $\beta$ in 293T cells and HeLa cells stimulated by $\mathrm{SeV}$ or poly(I:C). In addition, we try to explore the molecule mechanism by VZV to evade host innate immunity system especially the IFN- $\beta$ pathway. We found that ORF61 can inhibit the activity of IFN- $\beta$ promoter in 293T cells by reporter assays in the presence of $\mathrm{SeV}$ or poly I:C. The activity of ISRE (interferon-stimulated response elements, ISRE) promoter was also inhibited but not that of NF- $\kappa$ B promoter by ORF61, suggesting that ORF61 may interfere with the activity of IRF3. Ultimately, our results demonstrated that ORF61 degraded phosphorylation IRF3 via its E3 ubiquitin ligase activity. In one word, VZV ORF61 could inhibit IFN- $\beta$ pathway and may play a critical role in VZV pathogenesis.

Published: 10 January 2011

doi:10.1186/1753-6561-5-S1-P99

Cite this article as: Huifang and Zheng: Varicella zoster virus immediate early protein 61 blocks the IFN- $\beta$ pathway by degradation the activited IRF3. BMC Proceedings 2011 5(Suppl 1):P99.

State Key Laboratory of Virology, Wuhan Institute of Virology, Chinese Academy of Sciences, Wuhan 430071, PR China
Submit your next manuscript to BioMed Central and take full advantage of:

- Convenient online submission

- Thorough peer review

- No space constraints or color figure charges

- Immediate publication on acceptance

- Inclusion in PubMed, CAS, Scopus and Google Scholar

- Research which is freely available for redistribution
Biomed Central

\section{() Biomed Central}

(c) 2011 Huifang and Zheng; licensee BioMed Central Ltd. This is an open access article distributed under the terms of the Creative Commons Attribution License (http://creativecommons.org/licenses/by/2.0), which permits unrestricted use, distribution, and reproduction in any medium, provided the original work is properly cited. 